\title{
EFFECT OF CONCENTRATE LEVELS ON THE PERFORMANCE OF BEEF STEERS FINISHED IN CONFINAMENT
}

\author{
BREN, L. ${ }^{1}$; STRACK, A.G. ${ }^{2}$; PEROTTO, D. ${ }^{3}$; MOLETTA, J.L. ${ }^{3}$; KAPP, O. ${ }^{2}$ \\ ${ }^{1}$ Mestrando - Curso de Pós Graduação em Ciências Veterinárias - UFPR.; \\ ${ }^{2}$ Graduandos - UEPG. Bolsistas PIBIC CNPQ/IAPAR; \\ ${ }^{3}$ Pesquisador - Instituto Agronômico do Paraná.
}

The experiment was conducted at Estação Experimental Fazenda Modelo, Ponta Grossa, PR, with the objective of evaluate the effect of levels of concentrate in the diet on the performance of beef steers finished in confinament. Eighteen Canchim steers, with average age of 12 months and average weight of $309 \mathrm{Kg}$ were fed with corn silage "äd libitum" plus a concetrate containing $25 \%$ of soybean meal, $73 \%$ of ground corn grain and $2 \%$ mineral salt. The levels of concentrate in the diet were established on fases of live weight (PV), according to the following treatments: T1 (1\% of PV), T2 $(1,2 \%$ of $P V)$ and T3 (1,4 of PV). There was no significant difference $(P>0,05)$ with respect to the average daily gain, feed conversion and dry matter intake among treatments.

Key Words: feed in take, feed coversion, young steers, concentrate. 